\title{
臨床経験
}

\section{当院における腹腔鏡補助下胃切除術導入初期の成績一 胃癌症例の少ない地域において}

\begin{tabular}{|c|c|c|c|c|c|c|c|}
\hline 狩俣 & 弘幸 ${ }^{1)}$ & 長濱 & 正吉 ${ }^{1)}$ & 下地 & 英明 ${ }^{1)}$ & 桑原 & 史郎 ${ }^{2)}$ \\
\hline 片柳 & 憲雄 ${ }^{2)}$ & 山崎 & 俊幸 ${ }^{2)}$ & 大城 & 清哲 ${ }^{1)}$ & 伊禮 & 靖苗 ${ }^{1)}$ \\
\hline 石野信 & 一郎 ${ }^{1)}$ & 西巻 & 正 ${ }^{1)}$ & & & & \\
\hline
\end{tabular}

\section{内容要旨}

沖縄県は胃癌症例が少なく，胃癌手術の修練や新しい手術手技の導入は困難であるが，当院では腹 腔鏡補助下胃切除（LAG）を導入することができた。今回，導入にいたる経緯と導入初期の成績を検 討した，筆者はhigh volume centerでLAGの手術手技を研修し，2008年 4 月からLAGを当院に導入し た。それ以降, 2010年 3 月までに施行した腹腔鏡補助下の幽門側胃切除 (LADG) 11例, 胃全摘 (LATG) 7 例について導入直前 5 年間の開腹胃切除例（幽門側胃切除（ODG）20例, 胃全摘（OTG） 9 例）と 比較した，検討項目は患者背景, 手術時間, 出血量, 術後在院日数, 術後合併症, 郭清リンパ節個数 とした. LADGはODGと比較して有意に出血量が少量で術後在院日数が短く, 合併症も少なかった. またLATGはOTGと比較して有意に手術時間が長かったが, 術後在院日数は少なかった. 胃癌症例の 少ない沖縄県でも, 大きな問題なくLAGの導入が可能であった.

索引用語 : 腹腔鏡下手術, 胃切除, 胃癌

\section{はじめに}

腹腔鏡補助下胃切除術 (laparoscopy assisted gastrectomy；LAG）は2001年に公表された胃癌

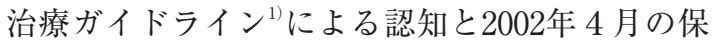
険収載によって, 導入する施設が増加している 2)-4). しかし, 胃癌症例の少ない地域では, LAGが 円滑に導入されているとは言い難い. 新しい手術 手技の導入にはトレーニング期間が不可欠である が, この時期の患者の不利益を極力減らすことが 重要で, トレーニング期間を短縮するにはそれ相 応の症例数が必要となる。この点を克服するため に，われわれはhigh volume centerで手術手技を

受付 : 2010年 7 月 9 日, 採用 : 2010年10月 26 日 連絡先 狩俣弘幸

干903-0215 沖縄県西原町字上原207

琉球大学大学院消化器 ·腫瘍外科学講座
習得し, 胃癌症例の少ない沖縄県にある当院で LAGを導入しえたので, その経緯と導入初期の成 績を報告する。

\section{背 景}

沖縄県では胃癌症例は少なく, 国立がん研究セ ンターがん対策情報センターの統計によると年間 胃癌死亡数は全国で最少であり (Fig. 1), 胃癌罹 患数は年間 300 例程度である. 2003年 4 月から 2008 年 3 月の 5 年間で当院の胃癌手術症例は86例で, 年間約17例であった $($ Fig. 2$)$. そのうち卒後10年 以下の若手外科医が経験した胃癌症例は32例で, それを10人で振り分けている (Table 1 )。このよ うに, 当院では胃癌手術症例が少なく, 開腹胃切 除のトレーニング, 教育さえも困難な状況であっ た。また, LAGの適応となるStage IA症例は年間 7,8 例程度で, LAGの新規導入はさらに困難で あった。 


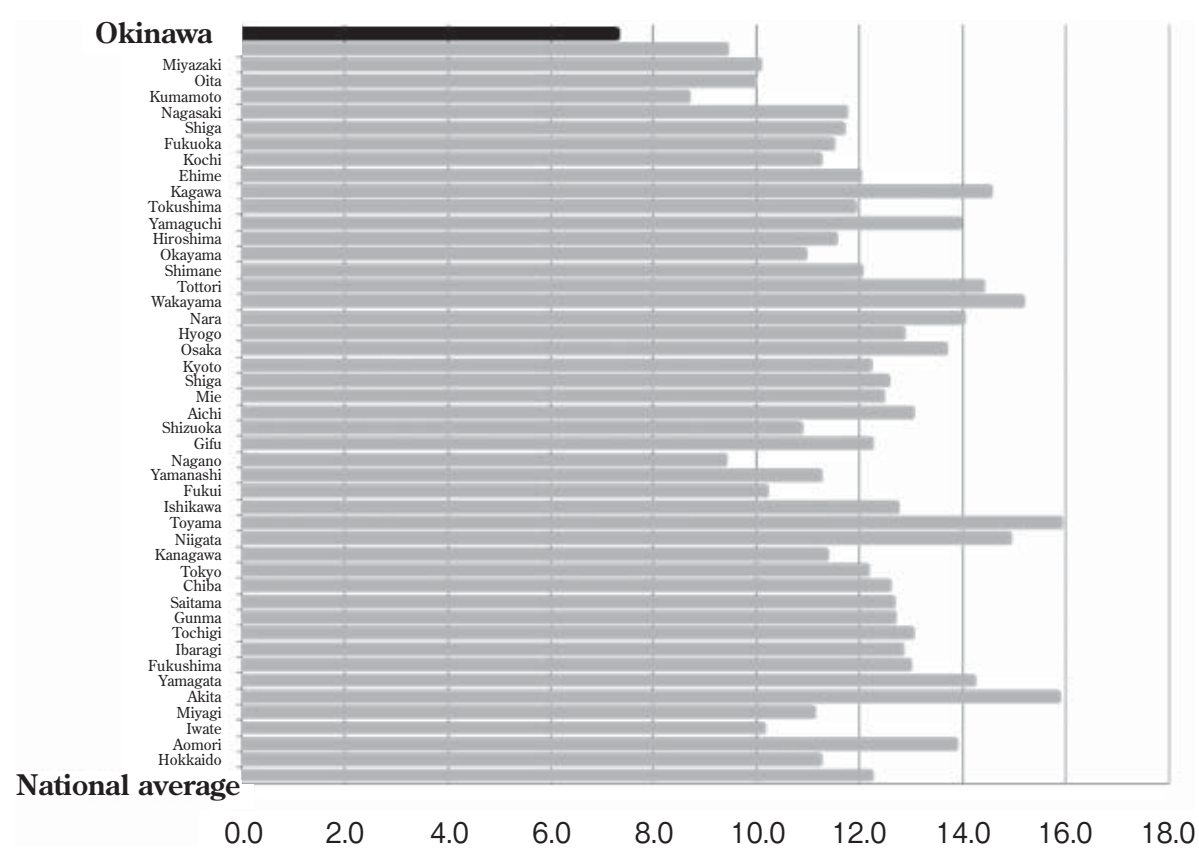

Fig. 1 Mortality for gastric cancer, age-specific rate over 75 years of age by prefecture: per 100000.

(Center for Cancer Control and Information Services, National Cancer Center, Japan)

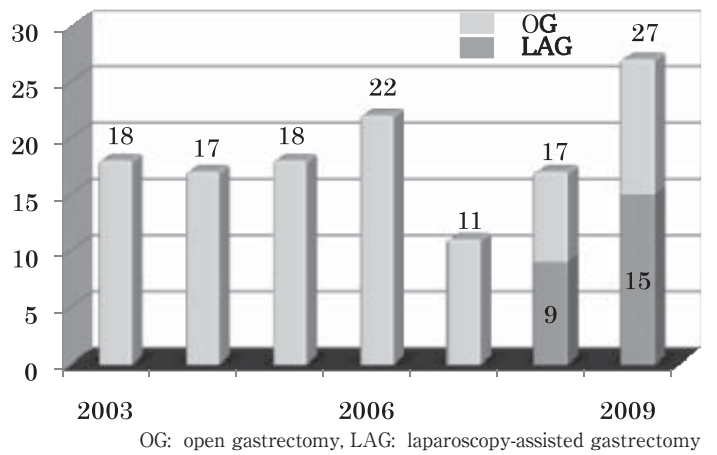

Fig. 2 gastric cancer surgeries by fiscal year.

筆者は2006年 4 月から 2 年間, high volume centerである新潟市民病院でLAGの手術手技を研 修し，2008年 5 月に内視鏡外科技術認定医を取得 した。研修時 9 年目で, 研修前の開腹胃切除経験 数は 8 例と少数であったが, 短期間に多くの症例 を集中して経験することで技術が習得でき， 2 年 の研修で内視鏡外科技術認定医の取得が可能とな った. High volume centerでの経験数はTable 2 に示す通りで, LAGの術者としての症例数は44例 で, 技術認定試験のビデオ症例は19例目であった.
Table 1 2003-2007 surgeries

\begin{tabular}{|l|c|}
\hline Less than 10 years surgeons & 32 cases/10 surgeons \\
\hline Surgeons over 10 years & 32 cases \\
\hline Professor on assistant professor & 22 cases \\
\hline
\end{tabular}

Table 2 Surgical experience

\begin{tabular}{|l|c|}
\hline \multicolumn{1}{|c|}{ Specialization } & Cases \\
\hline LAG surgeon & 44 \\
\hline Laparoscopist of LAG & 39 \\
\hline Laparoscopy cholecystectomy & 1 \\
\hline Laparoscopy appendectomy & 4 \\
\hline Laparoscopy-assisted colorectomy & 48 \\
\hline
\end{tabular}

この44例の平均手術時間は216分, 平均出血量は $24 \mathrm{ml}$ でった。帰局した2008年 4 月以降, 当院で は筆者を中心としてLAGを導入し, 現在まで術者 は筆者が行い，第一助手も固定している.

\section{LAGの手術手技}

筆者が研修した新潟市民病院外科の手技に準じ て行っており，ここでは幽門側胃切除について紹 介する。 ポートはFig. 3 のように挿入する. 術者 は患者左側に立ち,超音波凝固切開装置を用いて, 


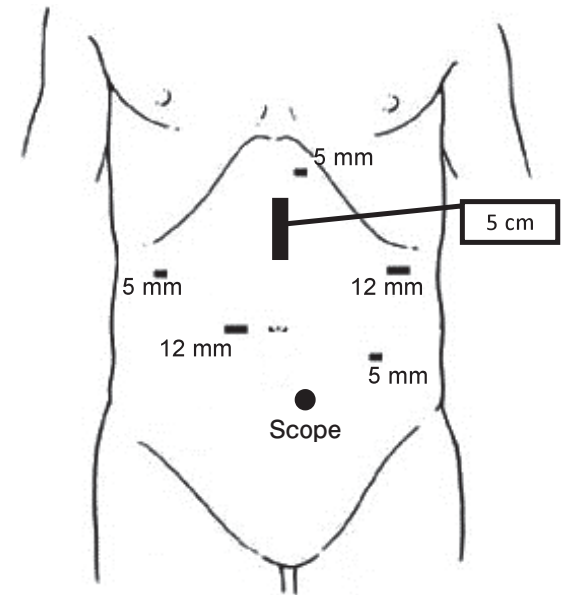

Fig. 3 Port insertion

大網切開を右胃大綱動静脈より $3 \mathrm{~cm}$ 離して右側 に向かって進めNo.4dのリンパ節を郭清する。切 開を十二指腸に進め, 前上膵十二指腸静脈の分岐 を確認し, 右胃大網静脈を根部でクリッピング切 離する.No.6リンパ節を郭清しながら胃十二指腸 動脈を同定. これより分岐する右胃大網動脈を根 部でクリッピング切離する。十二指腸壁沿いの脂 肪組織を切離する。術者は患者右側へ移り, 大網 の切離を脾門側へ進めて左胃大網動静脈を根部付 近でクリッピング切離する。十二指腸をリニアス テイプラーで離断する. 右胃動脈根部を剥離し, 根部でクリッピング切離し, No.5リンパ節の郭清 を行う。小網の切開を食道胃接合部まで進め, 横 隔膜右脚を露出する. 助手に胃膵ひだを牽引して もらいながら, No.8a, 9, 7 の郭清を行い, 左胃 動脈の根部を露出. 二重クリッピング切離する. 胃の背側, 腹側から小彎の剥離を行いNo.1，3の 郭清を行う。大彎側を胃壁にそって剥離した後, 上腹部正中に $5 \mathrm{~cm}$ の小開腹を行う. Wound protectorを挿入し, 十二指腸断端にタバコ縫合器を かけてアンビルヘッドを挿入する. 胃の切離線を

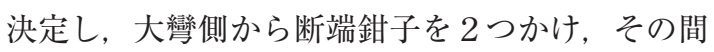
を切離する. 小彎側はリニアステイプラーで切離 する. 大彎側断端よりサーキュラーステイプラー を挿入し, 胃後壁大彎寄りにセンターロッドを貫 通させる. 十二指腸のアンビルヘッドとセンター ロッドを連結させて吻合する。サーキュラーステ イプラーの挿入口をリニアステイプラーで閉鎖す
る. 胃の切離断端は漿膜筋層縫合し補強している.

\section{対象・方法}

2008年 4 月からLAGを導入し，2010年 3 月まで に21例施行した．その内訳は腹腔鏡補助下幽門側 胃切除 (laparoscopic assist distal gastrectomy; LADG）が11例, 腹腔鏡補助下胃全摘（laparoscopic assist total gastrectomy; LATG) が 7 例, 腹腔鏡補助下噴門側胃切除 (laparoscopic assist proximal gastrectomy ; LAPG) が 3 例であった. LAGの手術適応は術前診断T1N0, 郭清度はD1+ $\alpha / \beta$ とした，対照は 2002 年 4 月から 2008 年 3 月 までに当院で行った開腹胃切除例のうち, 幽門側 胃切除 (open distal gastrectomy; ODG), 胃全 摘 (open total gastrectomy; OTG) 症例でD1+ $\alpha / \beta$ 郭清を行った29例とし, 以下の項目を比較 した。なお，LAG症例のうち, LAPGは再建法が 異なる（LAPGは食道残胃吻合, 開腹手術は空腸 間置) ため, 対象から除外した.

検討項目は, 患者背景として年歯, 男女比, body mass index (BMI) を, 手術項目として手術時間, 出血量を, 周術期項目として合併症の頻度, 術後 入院期間を,病理学的因子として郭清リンパ節個 数を比較した. 数值は中央值で示し， 2 群間の差 の検定にはMann-Whitney U testを用い, おのお の $\mathrm{p}<0.05$ を有意差ありとした。

\section{結 果}

\section{1. 患者背景の検討}

Table 3 に患者背景を示す。年齢, 男女比, BMI はLADG, ODGで差はなかったが, LATGとOTG の比較ではLATGに男性が多く, LATGで有意に BMIが高かった。

\section{2. 手術項目, 周術期の検討}

平均手術時間はLADGが348分, ODGが312.5分 と両者に差を認めなかった。他方, LATGは473 分, OTGが336分で, 全摘ではLATGが有意に手 術時間が長かった。出血量はLADGが70ml, ODG が264ml, LATGが284ml, OTGが435mlで, LAG で有意に少なかった. 術後在院日数はLADGが7 日, ODGが20日, LATGが16日, OTGが28日で, やはりLAGで有意に短かった (Table 3 )。合併症 はLADGではなく, ODGは 4例で, LADGで有意 に少なかった，他方, LATGでは 7 例中 3 例 (十二 
Table 3 LADG vs. ODG and LATG vs. OTG

\begin{tabular}{|c|c|c|c|c|c|c|}
\hline & LADG & ODG & $\mathrm{p}$ & LATG & OTG & $\mathrm{p}$ \\
\hline Number & 11 & 20 & & 7 & 9 & \\
\hline Age (min-max) & $59(35-86)$ & $63(29-86)$ & n. s. & $66(57-70)$ & $71(44-84)$ & n. s. \\
\hline Male : Female & $7: 4$ & $13: 7$ & n. s. & $7: 0$ & $7: 2$ & n. s. \\
\hline BMI & 23.9 & 23.4 & n. s. & 25.9 & 22.4 & $<0.05$ \\
\hline Operating time (min) & 348 & 312 & n. s. & 473 & 336 & $<0.05$ \\
\hline Blood loss & 70 & 264 & $<0.05$ & 284 & 435 & n. s. \\
\hline $\begin{array}{c}\text { Postoperative } \\
\text { hospitalization }\end{array}$ & 7 & 20 & $<0.05$ & 16 & 28 & $<0.05$ \\
\hline $\begin{array}{c}\text { Complications } \\
\text { Lymph nodes } \\
\text { dissected }\end{array}$ & 0 & 4 & $<0.05$ & 3 & 3 & n.s. \\
\hline
\end{tabular}

NS: not statistically significant

Table 4 Postoperative complications (cases)

\begin{tabular}{|c|c|}
\hline LADG & No complications \\
\hline ODG & $\begin{array}{l}\text { Anastomotic leakage : } 1 \\
\text { Surgical site infection : } 2 \\
\text { Delayed gastric emptying : } 1\end{array}$ \\
\hline LATG & $\begin{array}{l}\text { Duodenal stump leakage : } 1 \\
\text { Abdominal abscess : } 2\end{array}$ \\
\hline OTG & $\begin{array}{l}\text { Pneumonia: } 1 \\
\text { Surgical site infection : } 2\end{array}$ \\
\hline
\end{tabular}

指腸断端の縫合不全 1 例, 腹腔内膿瘍 2 例), OTG は 9 例中 3 例（創感染 2 例, 肺炎 1 例）認めた

(Table 4 ). なお, 手術時間, 出血量ともlearning curveはほとんどなかった（Fig. 4, 5 ）.

\section{3 . 病理組織学的因子の検討}

郭清リンパ節個数はLADGが26個, ODGが11個 とLADGで有意に多かった。他方, LATGは20個, OTGは16個で両者に差を認めなかった (Table 3 ).

\section{考察}

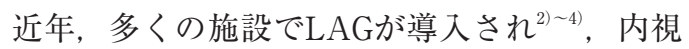
鏡外科学会のアンケートによれば, 2007年の胃癌 症例に占めるLAGの比率は $24.3 \%(4,765 / 19,603)$ と報告されている（日本内視鏡外科学会ホームぺ ージより).しかし, 症例数の少ない地域での新規 導入は技術的な問題から非常に困難で, 当院では high volume centerで研修後, その手技をもとに 導入した.

今回, 当院における $\mathrm{LAG}$ 導入初期の症例につい て，これまでの開腹手術症例と比較してみた。な お，この開腹手術症例であるが，他施設（high

volume ceter）の成績23) と比較して，100〜200分 程度手術時間が長時間であった。これは, 術者と なる卒後10年以下の医師の開腹胃切除経験数が少 なく，上級医による指導を受けながらの手術とな り，長時間を要したためと思われる.

LAG症例18例についてみると, high volume centerの定型化された手技に準じて行っており， 術者, 第一助手とも固定しているためlearnig curveはほとんどなく, トレーニング期間を必要 とせず導入することができた。 とくにLADGは ODGと比べて手術時間に差はなかった. LATGが OTGより手術時間が長かった理由としては, 腹腔 鏡手技の煩雑さも挙げられるが, LATGでは患者 のBMIが有意に高く, 手術の難易度が上がったこ とも理由の一つと思われた. 出血量はLAG症例が 有意に少なかった。これは, 腹腔鏡の拡大視効果 による緻密な操作と超音波凝固切開装置による止 血効果 ${ }^{2}$ によるためと考えられた. 術後在院日数も LAG症例が有意に短かく，これまでの報告 ${ }^{23)}$ と同 様, LAGの低侵襲性が示された.

術後合併症については, LADGではなかったが, LATGで合併症が認められた。合併症の内容は 十二指腸断端の縫合不全や腹腔内膿瘍で，手技の 問題による合併症と考えられ，より慎重な手術操 作, 手技の工夫が必要と思われた。 OTGとの比較 では合併症の内容が異なっていた。創が大きいこ とによる合併症と思われ，創感染や肺炎などは LATG群ではみられなかった。 なお, 再手術を要 
(a)

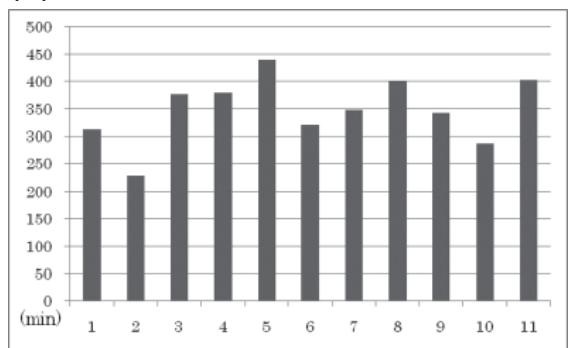

(b)

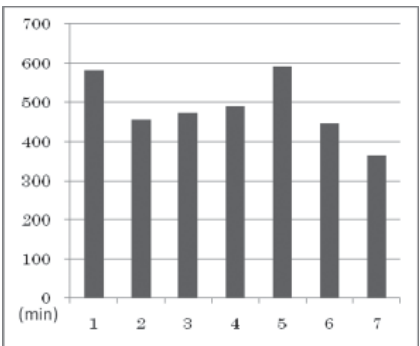

Fig. 4 Operation time (min) (a) Laparoscopy-assisted distal gastrectomy (LADG) (b) Laparoscopy-assisted total gastrectomy (LATG)

(a)

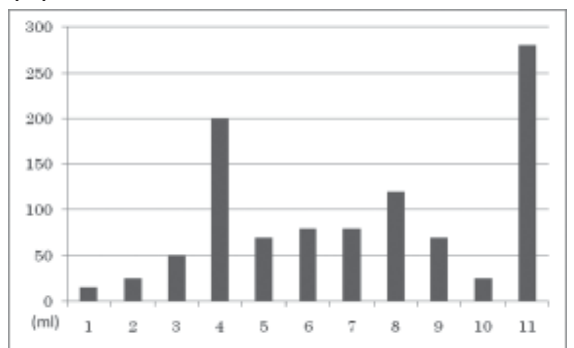

(b)

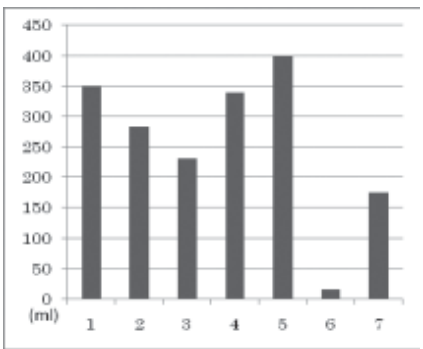

Fig. 5 Blood loss (ml). (a) LADG. (b) LATG

した症例はなかった．郭清リンパ節個数について も，LAG症例と開腹手術症例の間に有意差はな く, 適正な胃癌手術がLAGでも達成できることが 示唆された.

本検討から, 胃癌症例数が少ない沖縄県の当院 においても，今回のような経緯をとることで，大 きな問題なくLAGの導入が可能であった. 今後の 問題点として, LAGの術者が固定されているた め, 若手外科医の経験症例が減少することが挙げ られる，その解決策としては，筆者と同様にhigh volume centerでの研修で集中的に術者を経験し, 技術の習得をすることが一つの方法と考えられ る.また, 近年発達しているvirtual simulatorを使 つての技術習得も挙げられる. virtual simulatorに よるトレーニングは, 技術向上効果が認められる との報告 ${ }^{56)}$ も散見され, 今後simulatorなどの進歩 も含めて新たな展開が期待される.

\section{結 語}

胃癌症例の少ない地域である沖縄県の当院にお いてLAGを導入し, その成績を開腹手術と比較し た. High volume centerで習得した技術をもとに
導入したことで, 開腹胃切除に劣らない, またそ れ以上の成績が得られ, 大きな問題なくLAGの導 入が可能であった. 今後も症例を重ね, LAGの定 着を目指したいと考えている。

\section{文献}

1) 日本胃癌学会編：胃癌治療ガイドライン医師用 2004年 4 月改定．第 2 版，金原出版，東京，2004

2) 桑原史郎, 片柳憲雄, 松原洋孝, 他 : 早期胃癌に 対する腹腔鏡補助下幽門側胃切除（LADG）の初 期成績. 新潟医会誌 $5: 270-278,2006$

3）小島泰樹, 松井隆則, 小島 宏, 他：当院におけ る腹胅鏡補助下幽門側胃切除の導入一倫理的問 題に対する配慮および導入初期成績と後期成績 との比較. 日外科系連会誌 $33: 837-841,2008$

4）鈴木恵史, 富永幸治, 星野光典, 他：民間グルー プ病院における腹腔鏡補助下胃切除術の検討一 導入初期成績と技術支援について一. 日外科系連 会誌 $32: 632-637,2007$

5) Larsen CR, Soerensen JL, Grantcharov TP, et al: Effect of virtual reality training on laparoscopic surgery:randomaised controlled trial. BMJ 338: 1802-1808, 2009

6) 田上和夫, 橋爪 誠: 内視鏡外科手術における卜 レーニング．外科治療 $100 ： 291-297,2009$ 


\title{
A Study of Laparoscopy-Assisted Gastrectomy in an Area with Few Gastric Cancer Patients
}

\author{
Hiroyuki Karimata ${ }^{1)}$, Masayoshi Nagahama ${ }^{11}$, Hideaki Shimoji ${ }^{1}$, Shirou Kuwabara ${ }^{2)}$, \\ Norio Katayanagi $i^{2}$, Toshiyuki Yamazaki ${ }^{2)}$, Kiyotetsu Oshiro ${ }^{1)}$, Sanae Irei ${ }^{11}$, \\ Shinichiro Ishino ${ }^{1)}$ and Tadashi Nishimaki ${ }^{10}$ \\ ${ }^{1)}$ Department of Digestive and General Surgery, Ryukyu University, School of Medicine \\ ${ }^{2)}$ Department of Surgery, Niigata City General Hospital
}

Gastric cancer surgery training is difficult in Okinawa Prefecture due to the low number of gastric cancer cases, so we proposed that laparoscopy-assisted gastrectomy (LAG) be added to the surgical repertoire of hospitals in such areas. We thus under took a preliminary LAG study at our hospital.

From 2006 to 2008, a surgeon studied at a center with a large number of LAG operations, then LAG was introduced in April 2008 at our hospital. By March 2009, laparoscopy-assisted distal gastrectomy (LADG) had been done in 11 cases and laparoscopy-assisted total gastrectomy (LATG) in 7. Operation time, blood loss, postoperative hospitalization, complications, and lymph node dissection number were then compared to 20 cases of open distal gastrectomy (ODG) and 9 of open total gastrectomy (OTG) done from 2002 to 2008.

We found that LADG cases showed lower blood loss, shorter postoperative hospitalization, and fewer complications than ODG eases. LATG cases showed longer operation time than OTG cases but shorter postoperative hospitalization.

Our experience suggests that LAG be considered for addition to hospitaly repertoires in geographical areas with few gastric cancer patients.

Key words: laparoscopy, gastrectomy, gastric cancer 